\title{
Moral Conflicts Perceived by Students of a Project Course
}

\author{
Tero Vartiainen \\ Turku School of Economics, Pori \\ Unit, P.O. Box 170, FIN-28101 \\ PORI \\ Email: tero.vartiainen@tse.fi
}

\begin{abstract}
Regardless of the popularity of project courses in computing curricula, little is researched on moral issues in these courses. The aim of this study was to increase understanding in this area by determining what students on a project course in information systems (IS) perceived as moral conflicts. Data was gathered from diaries, drawings, interviews and questionnaires, and the analysis was inspired by phenomenography. The results show that the hardest moral conflicts were confronted when a student acted in a project manager's role, and that many originated in problems related to the group process. A two-dimensional structure of moral conflicts was found. The results are considered in the light of the existing literature, and implications for research and practice are presented.
\end{abstract}

\section{Keywords}

project-based learning, moral conflicts, group process

\section{INTRODUCTION}

Project work is a commonly used work method in the IT field, and is considered an essential component in educating future computer professionals [12]. The benefits of project courses are evident in that students acquire communications skills [27], and team-building and interpersonal skills [29], for example. In cases in which student projects are implemented for real-life clients [32] rather than being purely hypothetical, students gain valuable experience for the start of their careers. Indeed, collaborative student projects are a common form of industryacademia collaboration in the IT field [36]. This kind of collaboration benefits industry by producing results and opening up contacts to students - who are possible future employees. Experiences from project courses show that there are ethical issues to deal with $[8,30]$, but there are no in-depth studies about moral conflicts in IT projects in academia or in practice. This study aims to fill this gap by determining what students enrolled in a project course in information systems (IS) education perceive as moral conflicts.

In philosophical terms a moral dilemma is defined as a decision-making situation in which two incompatible actions are morally required [13, p.3]. A moral conflict is perceived as solvable and a moral dilemma as insolvable [15]. According to the broadest definition, a moral dilemma occurs in any situation in which morality is relevant [2]. In colloquial language the term moral problem is used, but for simplicity reasons, moral conflict is used in this empirical study. Examples of moral conflicts in computing, such as seeking balance between the quality of the information system and its cost, are found in Anderson et al [1].

This article is a partial report of a study investigating moral conflicts perceived by clients, students, and instructors on a project course [37]. Here, moral conflicts perceived by students are reported. Following this introduction, Section 2 reviews the literature related to the characteristics of small groups, group processes, and ethical issues in project courses. The research design is presented in Section 3, and the results in Section 4. Section 5 concludes the paper with some reflections on the results in the light of the literature.

\section{LITERATURE REVIEW}

A small group consists of three or more persons who are involved in social interaction aimed at achieving a common goal $[4,16]$. Indeed, the existence and all the actions of a group are geared towards the group goal [5]. Members share a set of values, they acquire or develop resources or skills, they conform to a set of norms, and they have a goal and leadership to coordinate their resources [14, p.4-5 and p.12-13]. The process of group decision-making includes task and social dimensions [9]. The task dimension refers to the relationship between the group members and the work they are to perform, and the social dimension to the relationships of the group members with one another. It seems that the task and social dimensions are highly interdependent. Group cohesiveness means the ability of the group members to get along with each other, thus determining their loyalty and commitment towards each other and the group, and could be seen as output from the group's social dimension. The output from the task dimension could be described as productivity. Cohesiveness and productivity are not easily determined, but they seem to have an interdependent relationship. The more cohesive the group is, the more productive it is. Cohesive groups are able to tolerate some differences in people, but too much variety in norms and values reduces the cohesiveness [9]. The above-mentioned task and social dimensions are visible in Tuckman's model of group development [33], which consists of forming, storming, norming, and performing stages. Later, Tuckman and Jensen [34] added the adjourning stage to the model (Table 1). At the forming stage, group members establish dependency relations with leaders and other group members, and pre-existing standards. They also test their boundaries of interpersonal and task behaviours. The storming stage involves conflict and polarization in relation to interpersonal issues as members resist the group influence and the task requirements. When resistance is overcome, at the norming stage, cohesiveness and in-group feelings develop, new standards evolve and new roles are adopted, and intimate and personal opinions are expressed. At the performing stage the interpersonal structure becomes the tool of task activities, and roles become flexible and functional: the group is targeted on the task. Finally, when the group's work is completed at the adjourning stage, the members feel anxiety and sadness.

The group process theory together with common knowledge shows that group work may occasionally be turbulent and there are conflicts to deal with. This being the case it is surprising 
Table 1: Stages of group process $[33,34]$

\begin{tabular}{|l|l|}
\hline Stage & Characteristics \\
\hline $\begin{array}{l}\text { Forming (orientation, } \\
\text { testing and } \\
\text { dependence) }\end{array}$ & $\begin{array}{l}\text { Testing and dependence; } \\
\text { Orientation to the task }\end{array}$ \\
\hline $\begin{array}{l}\text { Storming (resistance } \\
\text { to group influence } \\
\text { and task } \\
\text { requirements) }\end{array}$ & $\begin{array}{l}\text { Intragroup conflict; } \\
\text { Emotional response to task } \\
\text { demands }\end{array}$ \\
\hline $\begin{array}{l}\text { Norming (openness to } \\
\text { other group members) }\end{array}$ & $\begin{array}{l}\text { In-group feeling and cohesiveness } \\
\text { develop, new standards evolve } \\
\text { and new roles are adopted; } \\
\text { Open exchange of relevant } \\
\text { interpretations, intimate, personal } \\
\text { opinions are expressed }\end{array}$ \\
\hline $\begin{array}{l}\text { Performing } \\
\text { (constructive action) }\end{array}$ & $\begin{array}{l}\text { Roles become flexible and } \\
\text { functional, structural issues have } \\
\text { been resolved; } \\
\text { Interpersonal structure becomes } \\
\text { the tool of the task activities, } \\
\text { group energy channelled to the } \\
\text { task }\end{array}$ \\
\hline $\begin{array}{l}\text { Adjourning } \\
\text { (disengagement) }\end{array}$ & $\begin{array}{l}\text { Anxiety about separation, } \\
\text { sadness; } \\
\text { Self-evaluation }\end{array}$ \\
\hline
\end{tabular}

how rarely moral issues on project courses in computing are raised in computing literature. The following extract illustrates some problems in detail [30, p. 112]:

'... a) loners do not work well with others and want to "do their own thing", b) whistle blowing may not be done for various reasons, and c) handling the typical work ethic where "a few students do most of the work, some do just enough to get by and some do almost none."'

The above moral issues relate to individual students' acts and behaviour in the group. From the instructor's viewpoint, assigning meaningful grades is ethically difficult [30]. For example, whom should the instructor believe when a student or a team complains that another student or team is not doing its share of the work, or if a student complains that he or she would have been much more successful than the other students in accomplishing the project objectives?

Fielden [8] recalls experiences from over 10 years of conducting a student project course. Moral issues in student projects have emerged in the relationship between users and students when the users have had unrealistic expectations about what the students can accomplish. Problems also emerge when the student group does not come up with what was agreed when the contract with the client was signed. The same kinds of problems arise if one student from the group claims that it is able to accomplish something it cannot do (due to a lack of skills and expertise among the group members), or if there are different individual commitment levels. Dubious work practices in the client organization may also be cause for concern.

Ethics and morals relate to how individuals treat each other. As people in groups operate in close collaboration and as the stages of the group process theory show, there are conflicts to deal with. Therefore, students presumably face conflicts which have moral significance in their work. Next, the research design for increasing knowledge in this are is presented.

\section{RESEARCH DESIGN}

In order to identify moral conflicts in group-based project work and the same time to learn small group guidance work I started to work as the instructor. I applied participant observation [7] on an obligatory project course in IS curriculum in a Finnish university. Typically students participates the course in their third academic year and they represent ages between 20 and 25 . Students on this course are put into groups of five to implement a project task defined by a client, typically an IT firm such as a software house, or the IT department of an organization, such as an industrial plant. Each student is expected to use 275 hours in implementing the project task, and 125 hours to demonstrate project-work skills, including project leading, group work and communication skills. In total, a five-student group uses 1,375 hours in planning and implementing the client project. Each student is expected to practice the role of project manager for about one month during the process, which lasts from five to six months. The tasks range from extreme coding projects to developmental projects and research. The tasks are typically illdefined, and need to be redefined as the project progresses. A board consisting of two client representatives, two representatives from the student group (the project manager and the secretary) and the instructor make the redefinition and other decisions. During the collaboration, the role of the clients is to provide the students with guidance in terms of substance (e.g., technical guidance), and the role of the instructors is to guide the process (e.g., planning, reporting). Client organisations pay the university 8,500 euros for the co-operation. Once the supervising course instructor has accepted the clients, their representatives present the project tasks to the pre-formed student groups during the task-exhibition stage. The student groups then negotiate the tasks, and when clients and groups are allocated to each other the collaboration between a group and a client starts with an introductory meeting, the signing of the contract, and with the first board meeting.

During the project course, I arranged a voluntary ethics course for the students in order to develop their moral sensitivity and judgment [28]. I used student diaries, interviews, drawings and questionnaires, in which I encouraged the students to deliberate about moral conflicts they confront or could possibly confront. I encouraged them to express themselves openly in their own terms, an approach that allows complexities in moral actions to be taken into account [25, p.5]. Consequently, in line with the ideas of the interpretation theory [21], in order to reach understanding about moral conflicts the investigator has to interpret the subjects' statements to discover the meanings of their perceptions. The students were asked to use their diaries to reflect on the moral conflicts they confronted. During the first year (the academic period 1999-2000), the group members were required to write a common diary along with their personal diaries, but in later periods (2000-2001, 2001-2002) only personal diaries were used. In total, 13 individual students (coded S1...S13) and six student groups (coded G1...G6) wrote diaries (some of these groups were interviewed), 17 students (not involved in the ethics course) responded to a survey, and a total of 20 students produced drawings of moral conflicts during related exercises during the project course (some of these students later dropped out of the ethics course).

The analysis of the students' perceptions was inspired by phenomenography. The aim of the phenomenographical method is to identify and describe qualitative variation in individuals' experiences of their reality [23]. What is characteristic of the approach is that the aim is to capture conceptualisations that are faithful to the individuals' experiences of a selected 
phenomenon. These conceptions, which are typically gathered during interviews, are then categorised and relations between the categories are further explored [10]. A phenomenographic researcher seeks qualitatively different ways of experiencing the phenomena regardless of whether the differences are between or within individuals. He or she tries to achieve a socalled second-order perspective on the investigated aspect of the reality by describing the conceptions of a group of individuals - instead of taking the first-order approach and describing the reality directly, which is the convention in ethnographical studies (Figure 1) [18,35].

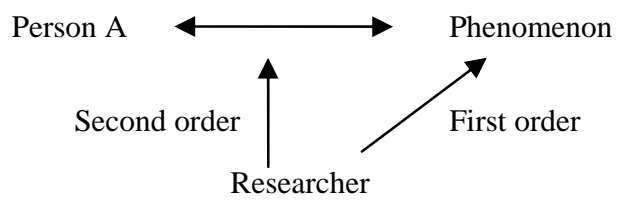

\section{Figure 1: The first and second order perspectives [18,35]}

In the analysis I coded the conflicts that emerged from the data (diaries, drawings, questionnaires) in order to acquire understanding of subjects' perceptions. Flap boards and the network views supplied in Atlas.ti software [24] helped me to visualize the categorization procedure. I grouped similar problems shared between the subjects, that is to say, I produced "pools" of moral conflicts. In this way I tried to achieve the second order perspective, abstractions of the issues towards what the subjects' deliberations were targeted. The separation to project task related issues and human issues became very clear: for example, deliberation about prioritizing between tasks and how a project manager should treat group members were logically allocated to different categories. While producing categorizations relating to the issues, I struggled with differences in the perceptions concerning the same issues. For example, regarding the human issues students deliberated on the one hand their own well-being and on the other hand well-being of the others. Moral psychology theories [20.26] led me to think about intentions behind the deliberations, and finally I concluded that the two dimensions describe the collective meaning structure of moral conflicts: the external and the internal dimensions. The dimensions and categorizations are presented in the following section.

\section{RESULTS}

The identified dimensions of moral conflict are presented first, and then the various categories are reported.

On the external dimension moral conflicts are divided into those involving outside parties, the project task, and human issues (the rows in Table 2). Outside parties relate to parties not involved in the particular project co-operation, but who are indirectly or directly influenced by it. Task-related moral problems refer to the attainment of objectives and the implementation of the tasks. The third group, human issues, relates to how individuals are treated in the project work. The identification of the internal dimension was based on objects of concern and care (the columns in Table 2). Here, the analysis was inspired by Piaget's [26] finding on children's development from egocentrism to perspective-taking, i.e., to the ability to take others into account. Taking care of others is perceived as more mature than only taking care of oneself. Thus, there are self-centred moral conflicts in which students are concerned about themselves. Although they may recognise other parties in their descriptions, they focus their concern and care on themselves and on their interests. Those experiencing otherdirected moral conflicts extend their concern and care to others. Although the subjects themselves and others are present in the descriptions, and although self-centred interests are visible, the interests of others are dominant.

Category 1: Benefiting at the expense of outside parties. In this category, student deliberation is targeted on outside parties and is motivated by self-centred interests. While outside parties are recognised, duties and obligations towards them are not followed. There is a possibility of benefiting at the expense of outside parties by carrying out an illegal or harmful act.

Two themes emerged: the unauthorised copying of software and stabbing the other group in the back. First, producing unauthorised copies of software was considered a morally wrong act but it was nevertheless common: some students confessed that they had done unauthorized copying during the project. According to the student interviewees, the copying of installation CD-ROMs was usual in these groups. Secondly, one group may improve its own (and other groups') status by causing harm to another group. One student responded in the questionnaire that it was possible for students to stab another group in the back. The students were aware that every user in the university network was able to read other groups' documents - including the contract and the project results. It was revealed in the questionnaire responses that they could have reported the group to the instructors.

Category 2: Taking care of outside parties. In this category, student deliberation was targeted on outside parties and was motivated by concern for them. These parties include the whole of society, other groups, and people dependent on the client.

First, the students were concerned about societal problems and how they should relate to them. They perceived that their acts would have an influence on those issues. The problems in question included preserving natural resources, the questionable business line of a client, and intellectual property rights.

Group G2 considered the business line of their client questionable, for example. They felt that weaker people were in danger, and that employee burn-out was caused by assigning an unreasonable number of work tasks to them. The students were bewildered about the effects of decisions made by one individual: "The business line of the client of [name of the project group] is questionable. ... one is able to destroy and seize firms that would be capable of surviving... On the one hand, for us as a project group, do we want to work in favour of creating a society based on ownership and speculation?"

Secondly, there were references to maintaining relations with other groups and taking them into account. Other groups may be perceived differently and co-operation may be based on different assumptions. For example, student S13 analysed how she should relate to the other groups when she observed them stealing materials from the project space, and how she should react to her group members who spoke ill of other group.

Thirdly, concern was expressed about the division of the project tasks among the student groups. The clients present their project tasks to the students during the task-exhibition phase at the beginning of the course, and after that the students divide the tasks among themselves. The just allocation of the tasks was perceived as very difficult because many groups strove after the same ones, and it seemed that satisfactory resolution was impossible. Fourthly, students took into account parties that were dependent on representatives of clients. 
Table 2: Categories of moral conflicts perceived by students

\begin{tabular}{|l|l|l|l|}
\hline \multicolumn{2}{|c|}{ The internal dimension } & \multicolumn{1}{c|}{ Self-centred } & \multicolumn{1}{c|}{ Other-directed } \\
\cline { 3 - 4 } The external dimension & $\begin{array}{l}\text { Motivation and concern is based } \\
\text { on the self. }\end{array}$ & $\begin{array}{l}\text { Motivation extends from self- } \\
\text { centred deliberation to fulfilling } \\
\text { one's duties and obligations and to } \\
\text { concern for others. }\end{array}$ \\
\hline $\begin{array}{l}\text { Outside } \\
\text { parties }\end{array}$ & $\begin{array}{l}\text { Relations with parties outside } \\
\text { the project group }\end{array}$ & $\begin{array}{l}\text { Category 1: Benefiting at the } \\
\text { expense of outside parties }\end{array}$ & $\begin{array}{l}\text { Category 2: Taking care of outside } \\
\text { parties }\end{array}$ \\
\hline $\begin{array}{l}\text { Project } \\
\text { task }\end{array}$ & $\begin{array}{l}\text { Attaining the objectives of the } \\
\text { project and implementing the } \\
\text { tasks. }\end{array}$ & $\begin{array}{l}\text { Category 3: Self-centred } \\
\text { deliberation related to the } \\
\text { project task }\end{array}$ & $\begin{array}{l}\text { Category 4: Fulfilling the project } \\
\text { tasks }\end{array}$ \\
\hline $\begin{array}{l}\text { Human } \\
\text { issues }\end{array}$ & $\begin{array}{l}\text { Treatment of the individuals, } \\
\text { who are participating in the } \\
\text { project. }\end{array}$ & $\begin{array}{l}\text { Category 5: Taking care of } \\
\text { oneself and one's interests }\end{array}$ & $\begin{array}{l}\text { Category 6: Taking care of the } \\
\text { individuals in the project }\end{array}$ \\
\hline
\end{tabular}

Those that emerged in the diaries were employees of the client organizations, and it was the possible harmful consequences of their acts to these parties that were of moral concern. Group G6 confronted a moral conflict when they analysed and wrote a report about their findings: protecting individuals' privacy would mean a loss of information from the final report. Getting useful results from the project was thus in conflict with protecting the employees of the organization. One student pondered on the effects of the results of their project on the employees of the client organisation in her drawing of a moral conflict: "Could we propose staff reduction as a result of our project work if the findings support this alternative?"

Category 3: Self-centred deliberation related to the project task. In this category student deliberation was targeted on the project task and was motivated by self-centred interests. Although other parties were recognised, obligations or duties towards them were not fulfilled. The category is based on students' observations concerning the inclination to avoid fulfilling one's duties, the use of university resources for one's own purposes, and carelessness in protecting confidential information.

First, the students felt that there was an inclination to avoid work tasks and to neglect the fulfilment of one's duties in the project work. Those in some groups observed other students avoiding tedious work tasks, guidance meetings and project managers' meetings. Student S8 stated that some of his fellow students tried to avoid work tasks: "I have noticed that within our group the level of commitment varies. They don't want to pick up the baton, and many of them seem keen to avoid work tasks." Secondly, moral conflicts were perceived in using university resources (e.g., copy machines) for purposes than other they were intended, namely for purposes based on selfinterest. The students considered that the use of university resources such as copy machines, printers and telephones was included in the moral conflicts related to the inclination to use such resources for their own purposes. Thirdly, they confessed that they had conducted presumably or genuinely immoral acts in formal contexts: dishonesty in the booking of hours and plagiarism in project plans were mentioned. Student S12 stated that they were perhaps morally wrong when they copied the framework plans of groups from previous years. Group G1 confessed that they had falsified information in the booking of hours: "From time to time the project group added to the number of hours they booked in order to conform to the university time limits." Fourthly, students showed concern for the protection of confidential information, but they may have been careless in implementing their concern. It appeared from their statements that confidential information could leak to outside parties if emails fell into the wrong hands, or if they were talking about confidential issues in public places. According to student S9, adhering to a confidentiality agreement was hard in practice because discussions that started in the project room tended to continue in the university canteen, for example. Moreover, client issues were discussed more or less publicly at student parties: "Many times it has happened that the group has continued client-related discussions that started in the classroom in a canteen full of people. ... The group members are obligated by the confidentiality contract, but following it seems to be hard in practice."

Category 4: Fulfilling the project tasks. Student deliberations in this category were targeted on the project task and motivated by concern for fulfilling the duties or obligations related to it. Although there were still self-centred concerns in the descriptions, there was also real concern about fulfilling duties and obligations for other parties. The following themes emerged: prioritising between project tasks and other issues, being careful about confidential information, complying with formalities in accordance with the rules, grading, and equal commitment to the project.

To start with prioritisation problems, students confronted moral conflicts related to the allocation of the time resources required for the work tasks and commitments such as other courses. Student S8 considered his position towards his fellow students' and his own time resources morally problematic. He tried to decide whether he should take care of the work tasks that others were not willing to do, and reflected upon this issue twice in his diary: “...I have plenty to do outside of the project, and I am not willing to sacrifice all my free time to it just because there is no agreement. Am I doing the wrong thing?" Student S6 observed that the aim to learn new technologies would not be most beneficial to the client, and using familiar equipment would be more efficient. The moral conflict in this case relates to the conflict between learning new skills and what is best for the client: "The group is obligated to produce a reasoned proposal about the implementation environment. Could the group members' wishes affect the choice of environment particularly if it would be undoubtedly useful for the client to use the environment about which the group has the best experience?"

The fact that there were unequal levels of commitment to the project was considered morally problematic in terms of student perceptions of how they reacted to such behaviour. Some of them stated in their questionnaire responses that there may be within group differences in commitment: some students are 
busier than others, and this affects the management of work tasks and timetables. As an example: "The Development Project course is very hard, and it is very tedious to complete other courses/to work simultaneously. It would be fair if all the group members allocated the same amount of their resources to the project - instead of taking on other work/courses to make their burden heavier and the scheduling more difficult" (questionnaire response). Figure 2 illustrates the same problem. The text in the drawing reads: "A group meeting. Where are the others?"

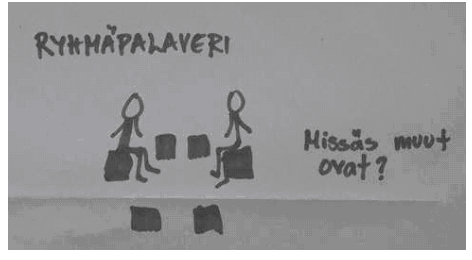

Figure 2. One student's drawing about a moral conflict.

Taking care of duties related to confidentiality was a concern for the students. The groups are encouraged to co-operate with each other by comparing their working methods and arranging brainstorming sessions, for example. Student S3 confronted a moral conflict when a student from their "synergy group" asked him what kind of education their client offered. The student did not know what he was allowed to talk about with other students, so he ignored the question. He faced a similar situation with his friends. The non-disclosure agreement forbade him from disclosing confidential information, but it was hard for him to understand what issues were included in the ban.

Students were bewildered about complying with project formalities in accordance with the rules. Should the compliance be strict, or was there some flexibility? The formalities in question were the booking of hours and the routines of board meetings. For example, student S8 noticed that the hours reserved for one phase had been exceeded, and he wondered whether he should reduce his own hours or tell the truth about having exceeded the allotted time. In any case, the booking of hours was problematic in terms of equality. The carrying out of work tasks may demand different amounts of time from students, i.e., there may be differences in efficiency, but still each one is required to use 375 hours for the project. Student S13 wrote in his diary about a disagreement with his fellow student over the booking of hours and the quality of his work: “... Of course, we others were not happy to do overtime, but someone had to do it to complete this project. Afterwards this feels unfair. [The name of the student] gave arguments for sticking to his guns: that he was more efficient than the others...."

The grading was considered morally problematic in itself because the assessment covered not only the group as a whole but also the individual members. The morality of giving different grades when every one's contribution was essential was raised - likewise the moral problem related to equal grading in cases in which all group members were not committed to cooperation. Student S2 deliberated about the problem of assigning different grades to group members: on the one hand each member was thought to play a significant role in the group, but on the other hand there were differences in commitment to the project, and such differences affected the group spirit. The following extract from student S2's diary reflects the problem: “... we started to produce the final assessment as group work. This raised a discussion about grades, because most of the group members thought that one of them did not deserve the same grade as the others. ... Perhaps it is wrong to put group members in an unequal position after six months of work, particularly because everyone's contribution was unique ... But it is self-evident that different working habits and schedules dampen the group spirit.” (S2)

Category 5: Taking care of oneself and one's interests. Student deliberation in this category is targeted towards human issues and the motivation is self-seeking. Although the needs of other parties are recognised, the real concern is with oneself. Concern for one's wellbeing, serving one's own interests, and causing harm to another individual emerged as causes for concern.

The students in this category perceived a moral conflict in their own wellbeing in the project. Student S3 stated: "One must learn to say that one doesn't have time, and to be honest about one's abilities - otherwise one burns out." Conflict was also perceived in the pursuit of one's own interests and the disregard of those of the group. Students pursued their own interests by influencing the possibility of gaining employment from the client, for example. Group G1 stated in their joint diary that at the end of the project some of them were more concerned about their own interests, and disregarded the project. The possibility of securing employment from the client led them to advertise themselves to its representatives. One student pondered in her drawing of a moral conflict (Figure 3) about her behaviour towards a client representative in terms of gaining benefit from it. The text in the figure reads: "A moral conflict. Should I dance attendance on the disgusting client representative if I know that it will further my career? Double-dealing"

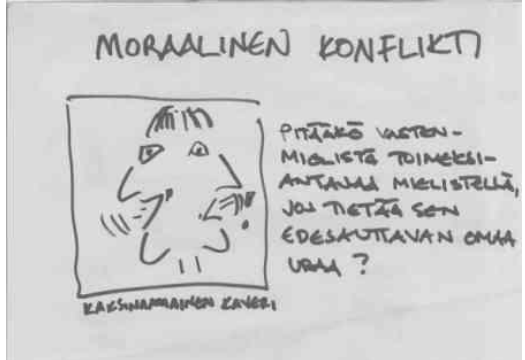

\section{Figure 3: One student's drawing about moral conflict in project work}

Bullying and harassment, which occasionally happened in the groups, could be interpreted as human-issues-related conflict: the student deliberates whether or not she will cause harm to another student. One student deliberated in her drawing on whether she could use her position as project manager to take revenge on her fellow student by assigning the most tedious work task to her: "Could I still use my position as a project manger to childishly take revenge [on my fellow student]?"

Category 6: Taking care of individuals. Student deliberation in this category is targeted on individuals and is motivated by concern for other people's well-being or for fulfilling duties or obligations towards other individuals. Students referred to taking individuals into account in assigning work tasks, intervening in someone's actions, and honesty and ways of interacting with clients and instructors in their descriptions. Students taking the role of project manager were concerned about the fellow-students to whom they assigned work tasks in terms of their ability to complete the tasks, their other activities that may be in conflict with the project tasks, and their efficiency. Student S2, in the project manager's role, confronted a moral conflict related to assigning a work task to a fellow- 
student whose ability to complete it was in doubt. On the one hand, he thought that, for the sake of honesty, he should probably tell the student of his concern, although the truth might hurt him. On the other hand, if he assigned the work task to him without taking any precautions, he might endanger the project. Another student produced two drawings (Figure 4). The first depicts a project manager ordering project workers about (with a whip in his hand), and a moral conflict between getting the job done and the group spirit emerges. The moral conflict is solved in the second drawing in that the project workers are having fun and at the same time they are able to produce results. In the left-hand picture the project manager is saying: "Make it snappy, you bastards! The deadline is drawing closer!!" His fellow students are complaining: "Ouch! We're tired but we have to work, Lord High and Mighty project manager." The text at the bottom of the figure reads as follows: "The final result vs. the group spirit (general wellbeing)" In the right-hand picture (representing the conflict as resolved) the project workers are saying: "Yeah! This is fun and the work is ready on time!" It could be concluded from the drawings that in attaining the final results a project manager may assign work tasks in either a repressive or a constructive way from the group-spirit perspective.

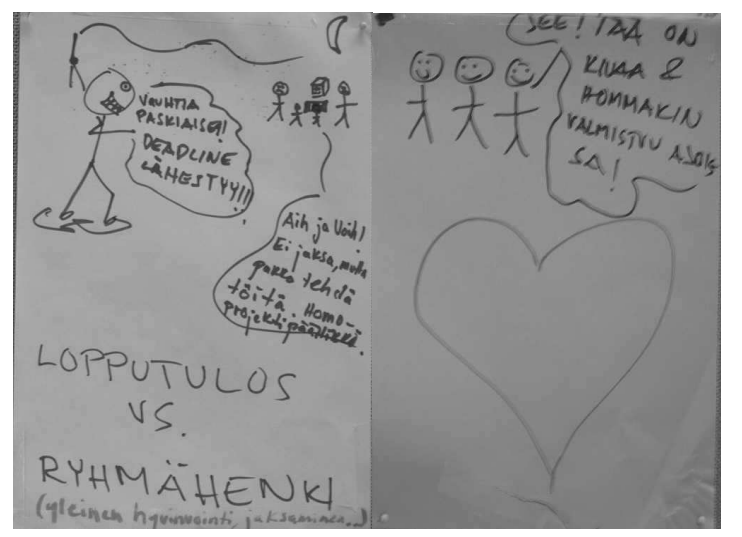

Figure 4. One student's drawing of a moral conflict in project work, and the conflict as solved

Some students confronted moral conflicts in which they had to think about whether they should intervene in another student's activities. The reasons for the possible interventions included the other student's irresponsible, ineffective, harmful, or evil behaviour. For example, in his role as a project manager, student S11 did not accept his fellow-student's not taking part in correcting the defects found in a document during inspection. He pondered on whether he should have intervened to change this student's behaviour.

Students perceived honesty-related moral conflicts in their cooperation with representatives of clients and university instructors. For example, student S2 speculated over whether refraining from telling a lie was the same as telling one. When his group presented a prototype of a future system they did not disclose all the problems they were struggling with. Student S2 considered this a white lie that did not harm the project, and in the end they fixed the problems. Student $\mathrm{S} 1$ confessed that he was not fully honest in the final assessment because he did not reveal the real state of the relationship between him and another student (the other student had done something to offend student S1). S1 reasoned that, because he had a problem with only one student, and because problems with colleagues were not rare, he would not reveal his problem.

\section{DISCUSSION}

The results of this study increase understanding about moral conflicts in project work in a project course. The external division of moral conflicts into those related to outside parties, to project tasks, and to human issues well describes their themes. This division has its counterparts in the literature on group processes (task and social dimensions; [9]) and management. The classical managerial grid [3] consists of two aspects and their underlying concerns: management (concern for production) and leadership (concern for people). Indeed, students in the project manager's role had to tackle the hardest moral conflicts related to implementing the project task (concern for production), while at the same time upholding the group members' motivation (concern for people). Assigning work tasks and intervening in fellow-students' actions were, according to my interpretation, found by these novice managers to be the hardest moral conflicts. In addition to this, the students perceived that their projects had an indirect or direct influence on outside parties (e.g., employees of the client organisation). Indeed, the triplicity of external relations together with task and human issues has been recognised in the IS literature: project managers in information-systems development need skills in external relations together with task/project management and leadership skills [31], and project managers confront conflicts related to external stakeholders, managing the project (e.g., competition for scarce resources, differences related to goals) and interpersonal issues [17].

As far as these upper-level themes are concerned, the internal dimension uncovers the moral dimension as it denotes the intention behind the deliberation, which may be self-centred or other-directed. Students experiencing self-centred moral conflicts face temptations to break societal or group norms for egoistical reasons, such as getting software without paying for it and laziness in carrying out work duties. In these cases, when students are aware of that they break a norm or act against a moral value which they adhere to, their moral motivation, i.e. motivation to prioritize moral values above non-moral values [28], failed. However, not all self-centred moral conflicts relate to breaking a norm, and some involve concern for one's welfare (cf. upholding self in [11]). The interpretation adopted here, that egoism-based moral conflicts are forms of conflict perceived by the subjects, is supported by the results of studies on moral psychology, which recognise egoistical impulses as possible aspects (e.g., [25]). Students facing other-directed moral conflicts engage themselves in perspective taking, i.e., they are genuinely concerned about how the project work will affect outside parties, whether the duties and obligations relate to the work tasks fulfilled, and how the group members are affected.

The results suggest that the developmental stage of group process in student groups may correlate with the severity and emergence of the moral conflicts confronted by their members. Many descriptions of such conflicts suggest similarities with the forming and storming stages [33] in the process of group development. Some of the self-centred conflicts encountered in this study indicate that not all of the group members were equally loyal or committed to the project task or to other members, given the noted avoidance of fulfilling one's duties and even harassment. As a consequence, other-directed moral conflicts arose in which project managers were forced to deliberate on how to intervene in the actions of group members showing this kind of behaviour. Building trust, a sense of togetherness and loyalty in these groups might have prevented these conflicts. Of course, individual student's sense of responsibility affect to his or her behaviour. It is suggested that 
relationship conflicts are more disruptive than task conflicts [6]. Presumably, groups experiencing human-issue problems are not as productive as groups with high cohesiveness. To sum up, these results suggest that the moral dimension (self-centred and other-directed concerns) is inherent in intra- and extra-group relations in student groups. Not all decision-making situations involve moral conflicts, but their emergence could be perceived as an inherent part of group work.

Implications for research and practice. Given the fact that the subjects of this study represent the Finnish population, similar research in other countries might reveal cultural differences. Although the project tasks were real, the research setting was an educational institute. There is thus a need for a similar study in a working-life setting. Other aspects of moral behaviour, and moral decision-making and the implementation of those decisions [20,28], should also be investigated in the context of project work.

For educators, this study reveals moral conflicts students confront on project courses. As those assuming the project manager's role faced the hardest of these problems, it is suggested that students should be introduced to the leadership problems that beset those in managerial positions (e.g., [22]). In the case of the researched project course, students appeared to experience stress and anxiety in the collaborating with the outside client and other group members. Therefore, it is important to encourage students to take care of themselves and others. Additionally, ways of developing group cohesiveness should be introduced at the beginning of the course in order to foster the group process. This study offers examples on what happens in non-cohesive groups.

This study shows that practical project work is a fertile ground for ethics teaching. According to my practical experiences, it is possible to integrate ethics into project work. The external and internal dimensions of moral conflicts could be used as an instrument to develop students' moral sensitivity [28], and an introduction to ethics theory would assist them in the resolution process.

Evaluation of the study. The research is evaluated by principles put forward by [19] and the full description of the evaluation is to be found in [37]. Next, the principles with the most significant importance in relation to this study are considered.

First, the fundamental principle of hermeneutic circle is considered. The principle of hermeneutic circle is the basis for hermeneutics. This principle suggests that human understanding is achieved by iterating between the parts and the whole. In other words, we come to understand a complex whole from the meanings of its parts and their interrelationships and by iterating back and forth with interpretations until unresolved contradictions or gaps are filled. The principle of hermeneutic circle is actualised in this interpretive study by determining categories with external and internal dimensions, which constitute the second order perspective of students' perceptions.

Second, two principles, principle of interaction between the researchers and subjects, and the principle of suspicion are considered. The most influential source of bias in the data gathering was my presence and activities at various stages as a researcher, an instructor, and an ethics teacher. As ethics teacher I provided students with basic concepts relating to morals and ethics and directed them to deliberate about real moral conflicts they confront during the course. This may be considered both as strength and weakness of this study: the teaching intervention most probably steered students to deliberate issues, which they would not have otherwise deliberated. But from students' viewpoint fears of being shown up were significant, and therefore it is impossible to assess what they left untold, changed, or even invented in their expressions because of my triple role. In addition to this, as instructor I was to evaluate some students' performance. Before I started my instructor's job a student told me, "If you were the instructor, there might not be moral conflicts at all", suggesting that students would not be able to reveal such conflicts to their instructor. Although this statement is worthy of note, it turned out that the students described moral conflicts in detail in their diaries, and they sometimes expressed criticism of and frustration with the university, the instructors, the clients, and their fellow students alike.

Third, according to the principle of abstraction and generalization the researcher has to show how the abstractions and generalizations relate to the field study details. Although, in interpretive studies, very unique circumstances are investigated, these unique instances may be related to ideas and concepts, which apply to other situations. In the research design I reported how I collected and analysed data and in the results section the dimensions and categorizations are presented together with extracts from the data. Taken the issue of generalizing the results it is noteworthy that because this study is an in-depth case study by nature, the results are not directly generalizable to other project courses. However, the results point out some problem areas, which could be deliberated in other student projects courses - especially in the courses resembling the course I studied. The comparison with the relevant literature strengthens the view that the most significant features of moral conflicts in student projects are visible.

\section{REFERENCES}

[1] Anderson, R.E., Johnson, D.G., Gotterbarn, D., Perrolle, J. 1993. Using the New ACM Code of Ethics in DecisionMaking. Communications of ACM 36 (2), 98-107.

[2] Audi, R. (Ed.) 1995. The Cambridge Dictionary of Philosophy. Cambridge: Cambridge University Press.

[3] Blake, R.R., Mouton, J.S. 1978. The New Managerial Grid. Houston: Gulf Publishing Company. Rererenced in F.E. Kast, J.E., Rosenzweig 1985. Organization \& Management, A Systems and Contingency Approach. New York: McGraw-Hill.

[4] Boethius, S.B. 1983. Autonomy, Coping and Defense in Small Work Groups. Stockholm: Department of Psychology, University of Stockholm. Dissertation.

[5] Brown R. 2000. Group Processes. Oxford: Blackwell Publishers.

[6] De Dreu C.K.W. Weingart L.R. 2003 Task Versus Relationship Conflict, Team Performance, and Team Member Satisfaction: A Meta-Analysis. Journal of Applied Psychology 88 741-749.

[7] Fetterman, D.M. 1998. Ethnography: Step by Step. Thousand Oaks: Sage.

[8] Fielden, K. 1999. Starting Right: Ethical Education for Information Systems Developers. In C.R. Simpson (Ed.) AICEC99 Conference Proceedings, 14-16 July 1999. Melbourne. Brunswick East, Victoria: Australian Institute of Computer Ethics. 147-156. 
[9] Fisher, B.A., Ellis, D. 1990. Small Group Decision Making, Communication and the Group Process. New York: McGraw Hill.

[10] Francis, H. 1993. Advancing Phenomenography. Nordisk Pedagogik 13 (2), 68-75.

[11] Gillian, W.R., Krebs, D.L. 2000. The construction of moral dilemmas in everyday life. Journal of Moral Education 29 (1), 5-22.

[12] Gorgone, J.T., Davis G.B., Valacich, J.S., Topi, H., Feinstein, D.L. Longenecker, H.E.Jr. 2002. IS 2002. Model Curriculum and Guidelines for Undergraduate Degree Programs in Information Systems. Communications of AIS 11, Article 1.

[13] Gowans, C.W. 1987. The Debate on Moral Dilemmas In C.W. Gowans (Ed.) Moral Dilemmas. New York: Oxford University Press. 3-33.

[14] Hare, R.M. 1976. Handbook of small group research. New York: Free Press. Referenced in Hare, A.P., Blumberg, H.H., Davies, M.F., Kent, M.V. 1995. Small Group Research A Handbook. Norwood, New Jersey: Ablex Publishing Corporation.

[15] Hill, T.E. 1996. Moral Dilemmas, Gaps, and Residues: A Kantian Perspective. In H.E. Mason (Ed.) Moral Dilemmas and Moral Theory. New York: Oxford University Press. 167-198.

[16] Hollander, E.P. 1971. Principles and Methods of Social Psychology. New York: Oxford University Press. Referenced in Boethius, S.B. 1983. Autonomy, coping and defense in small work groups. Stockholm: Department of Psychology, University of Stockholm. Dissertation.

[17] Jurison, J. 1999. Software Project Management: the manager's view. Communications of Association for Information Systems. Vol 2, Article 17.

[18] Järvinen, P. 2001. On Research Methods. Tampere, Finland: Opinpaja Oy.

[19] Klein, H.K., Myers, M.D. 1999. A Set of Principles for Conducting and Evaluating Interpretive Field Studies in Information Systems. MIS Quarterly 23 (1), 67-94.

[20] Kohlberg, L. 1981. The Philosophy of Moral Development, Moral Stages and the Idea of Justice. San Francisco: Harper \& Row.

[21] Little, D. 1991. Varieties of Social Explanation. An Introduction to the Philosophy of Social Science. Boulder: Westview Press.

[22] Manning, F.V. 1981. Managerial Dilemmas and Executive Growth. Reston, Virginia: Reston Publishing.

[23] Marton, F. 1986. Phenomenography - a research approach to investigating different understandings of reality. Journal of Thought. 21 (3), 28-49.

[24] Muhr, T. 1997. Atlas.ti. A software programme. Berlin: Science Software Development.

[25] Packer, M.J. 1985. The Structure of Moral Action: A Hermeneutic Study of Moral Conflict. Basel: Karger.

[26] Piaget, J. 1977. The Moral Judgement of the Child. Harmonsdsworth: Penguin.
[27] Pigford, D.V. 1992. The Documentation and Evaluation of Team-Oriented Database Projects. Proceedings of the twenty-third technical symposium on Computer science education. Kansas City, Missouri, United States. New York: ACM Press. 28-33.

[28] Rest, J. 1984. The Major Components of Morality. In W.M. Kurtines, J.L. Gewirtz (Eds.) Morality, Moral Behavior, and Moral Development. New York: A WileyInterscience Publication. 24-38.

[29] Roberts, E. 2000. Computing Education and the Information Technology Workforce. SIGCSE Bulletin 32 (2), 83-90.

[30] Scott, T.J., Tichenor, L.H., Bisland, R.B.Jr., Cross J.H. 2003. Team dynamics in student programming projects. SIGSCE 26 (1), 111-115.

[31] Semprevivo, P.C. 1980. Teams in Information Systems Development. New York: Yourdon Press.

[32] Tourunen, E. 1992. Educating reflective system designers by using the experiential learning mode. In B.Z. Barta, A. Goh, L. Lim (Eds.) Professional Development of Information Technology Professionals. Amsterdam: Elsevier Science Publishers. 113-120.

[33] Tuckman, B. W. (1965) "Developmental Sequence in Small Groups", Psychological Bulletin, Volume 63, Number 6, pp. 384 99, American Psychological Association.

[34] Tuckman B.W., Jensen M.A. (1977) Stages of small-group development revisited. Group Org. Studies 2: 419-427.

[35] Uljens, M. 1991. Phenomenography - A Qualitative Approach in Educational Research In L. Syrjälä, J. Merenheimo (Eds.) Kasvatustutkimuksen laadullisia lähestymistapoja. Kvalitatiivisten tutkimusmenetelmien seminaari Oulussa 11.-13.10.1990. Esitelmiä. Oulun yliopiston kasvatustieteiden tiedekunnan opetusmonisteita ja selosteita 39, 1991.

[36] Ziegler, W.L. 1983. Computer science education and industry: Preventing educational misalignment. In E.M. Awad (Ed.) The Proceedings of the Twentieth Annual Computer Personnel on Research Conference, Charlottesville, Virginia, USA. November, 10.

[37] Vartiainen T. Moral Conflicts in Project Course in Information Systems Education. Diss. Jyväskylä Studies in Computing 49. Jyväskylä: University of Jyväskylä. 